\title{
ACQUIRED TUFTED ANGIOMA
}

\author{
D. Prem Charles ${ }^{1}$, K. Murali² ${ }^{2}$ C. S. Subramanian ${ }^{3}$, U. Manohar ${ }^{4}$, P. Viswanathan ${ }^{5}$
}

\section{HOW TO CITE THIS ARTICLE:}

D. Prem Charles, K. Murali, C. S. Subramanian, U. Manohar, P. Viswanathan. "Acquired tufted angioma". Journal of Evolution of Medical and Dental Sciences 2013; Vol2, Issue 35, September 2; Page: 6784-6787.

ABSTRACT: The acquired tufted angioma was not a well known clinical entity which may simulate Kaposi Sarcoma histologically. It was a rare benign vascular tumor of unknown pathogenesis. Twenty five percent are congenital and fifty percent appear in the first year of life. The clinical presentation was non specific with a high predilection for the head, neck and thoracic region. We are reporting two cases of acquired tufted angioma both of which presented as pain less welling in the lower limb. This unusual presentation of this lesion signifies this publication.

KEYWORDS: Acquired tufted angioma, Kaposi sarcoma, lower limb.

INTRODUCTION: Tufted angioma was an uncommon benign vascular neoplasm, localized to the skin and subcutaneous tissues with no documented systemic or metastatic involvement. Tufted angioma were described in the literature under different names including Nakagawa's angioma, Nakagawa's angio blastoma, progressive capillary hemangioma and acquired tufted angioma of the skin and subcutaneous tissue. ${ }^{1}$ Tufted angioma was more common in the Asian population. However numerous cases have been reported in Europe. ${ }^{2}$ Cases have been reported to occur during pregnancy ${ }^{3}$ with spontaneous resolution after child birth, and one case, which ultimately regressed spontaneously, developed after a liver transplant. ${ }^{4}$ Myamato and others reported a case that exhibited partial spontaneous regression. Tufted angioma was characterized by slow angiomatous proliferation with no racial predilection and occurs equally in both sexes. The lesions are usually symptomatic but painful episodes have been described. ${ }^{5}$

CASE HISTORY: A 42 years male presented with a swelling in the lateral side of the right foot for a week. Local examination revealed a swelling of $4 \times 3 \mathrm{~cm}$, spherical in shape, mild tenderness present, mobile, transillumination negative. Initial clinical diagnosis of Ganglion right foot was made. Excision biopsy was performed on the lesion and sent for histopathological examination. Macroscopy reveals grey white tissue piece measuring $1 \mathrm{ml}$ in aggregate.

A 37 years male presented with a swelling in the right lateral malleolus of 10 days. Local examination revealed a swelling of $5 \times 4 \mathrm{~cm}$, spherical in shape, non tender, mobile and soft in consistency. Initial clinical diagnosis of Implantation dermoid right foot was made. Excision biopsy was performed and sent for histopathological examination. Macroscopy reveals grey white tissue piece measuring $4 \times 2 \mathrm{~cm}$.

MICROSCOPY: Collections of small blood vessels appear in the form of slit like spaces which contain RBC's. There are areas of collection of cells which are spindle shaped and have plump nuclei which appears to be of endothelial origin. In some of the areas, the newly formed blood vessels appear like epithelioid hemangioma. There was a vague lobulation of the lesions. Areas of hemorrhage and thrombosis present and there was significant number of inflammatory cells with predominance of lymphocytes and plasma cells. 
Features are consistent with Acquired Tufted Angioma

DISCUSSION: Described by Wilson Jones \& Orkin6in 1989.More than fifty percent cases of acquired angioma occur within the first year of life and most of cases of tufted angioma develop before the age of five, fewer than fifty percent of cases with tufted angioma are older than 50 years. In individuals older than 60 years the disease was very rare.7Tufted angioma presents clinically as ill defined slowly progressive dull red, brownish or purple macules or plaques with mottled surfaces. The lesion was described as solitary and rarely involves the subcutaneous tissues. It slowly enlarges over six months to ten years; after which no further growth ${ }^{8}$ occurs. No causes of tufted angioma have been established. Trauma does not appear to be a predisposing factor, although a report describes the appearance of a lesion of tufted angioma at the site of previous arthropod bite. The sites most commonly involved are the upper trunk, neck and shoulder. Less commonly the face, scalp and proximal extremities. The lesion slowly progresses and covers the wide segments of the body. Partial regression may occur but complete regression was rare. ${ }^{9}$ Microscopically there was circumscribed foci of closely set capillaries scattered through the dermis, discrete ovoid and angiomatous lobules give rise to canon ball appearance.10Vascular lumina are compressed by enlarged endothelial cells and contain few RBCs. Immuno histochemistry shows actin as a perithelial component ${ }^{11}$ among the tumor capillaries, also there was positivity for $\mathrm{VwF}$ usually limited to a few vessels. ${ }^{12}$ Most of the features resemble juvenile hemangioma, ${ }^{13}$ more likely represents a limited form of Kaposi form hemangioendothelioma in an adult unassociated with Kassabach-Merrit syndrome.

\section{DIFFERENTIAL DIAGNOSIS:}

KAPOSI SARCOMA: In Kaposi sarcoma there will be elongated spindle cells with background shows extensive haemorrhage.

ACKNOWLEDGEMENT: We take the privilege of thanking the Dean and the Medical Superintendent, Faculty of Medicine, Dr. L. Lakshmana Rao, H.O.D., Department of Pathology, and the patient, for allowing us to take on this case for presentation.

\section{REFERENCES:}

1. Alessi.E,Bertani E,sola F: Acquired Tufted Angioma.AM.J.Dermatopathol 1990 ;8:426-9.

2. Wilson - Jones E. Malignant vascular tumors. Clin Exp Dermatol. 1976; 1: 287-312.

3. Kim YK, Kim HJ, Lee KG. Acquired Tufted Angioma associated with pregnancy. Clin Exp Dermatol 1992; $17: 458-9$.

4. Chu P, LeBoitPE. An eruptive vascular proliferation resembling acquired tufted angioma in the recipient of a liver transplant. J Am Acad Dermatol 1992; 26(2 P 2): 322-5.

5. Frenk.E,Vion B,Merol Y etal: Tufted Angioma.Dermatologica $1990 ; 181: 242-3$.

6. Wilson Jones E, Orkin M.Tufted angioma (angioblastoma): a benign progressive angioma, not to be confused with Kaposi's sarcoma or Low grade angiosarcoma.J Am Acad Dermatol 1989; 20:214.

7. Jang KA, choio JH, Sung KJ et al : congenital lineal angioma Br.J.Dermatol 1998 ;138:12-13. 
8. LamWY, MacMoune - Lai F, Look cn et al: tufted angioma wth complete regression. Pathol 1994; 21: 461-6.

9. Fukunaga M : Intravenous tufted angioma APMIS $2000 ; 108: 287-292$.

10. Wilson Jones E.Orkin.M.Tufted angioma:a benign progressive angioma, not to be confused with Kaposi's sarcoma or low grade angiosarcoma.J AM Acad Dermatol1989; 20:214.

11. Padilla.RS , Orkin M.Rosai.Juvenille acquired tufted angioma.Am.J.Dermatopathol 1987:9:292.

12. Wilson Jones E,Orkin M.Tufted angioma: a benign progressive angioma, not to be confused with kaposi sarcoma or low grade angiosarcoma.J Am ACAD Dermatol 1989;20:214.

13. Kumakiri M, Muramoto LF, Tsukinga I, et al.Crystalline lamellae in the endothelial Cellsof a type of hemangioma characterised by the proliferation of immature Endothelial cells and pericytes angioblastoma( Nakagawa).J A Acad Dermatol 1983; 8:68.

All the microscopic pictures were taken using Nikon cool pix model 8400

$\mathrm{X}$ indicates the power of objective

Stain used - Haematoxylin \& Eosin.

\section{CASE HISTORY 1 :}

Fig 1 : H \& E stained $4 X$

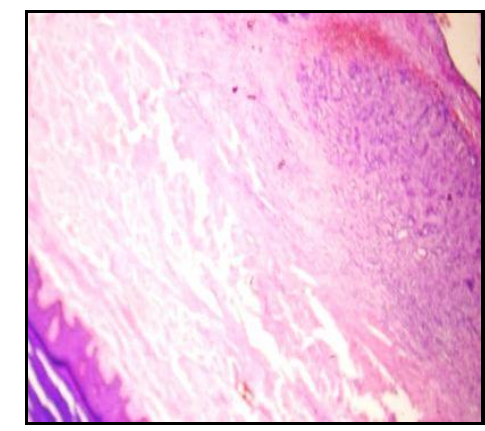

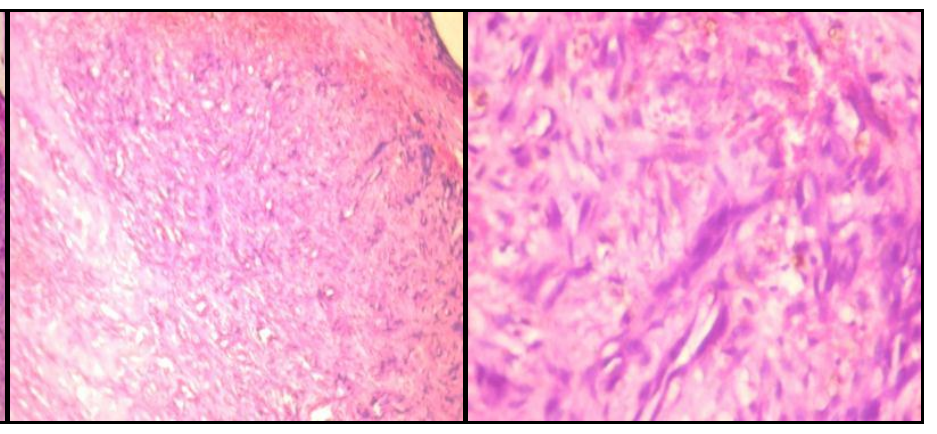

10X
20X

Collection of Capillaries Lined by Endothelial cells; Slit iike Spaces and Areas Of haemorrhage

\section{CASE HISTORY 2 :}

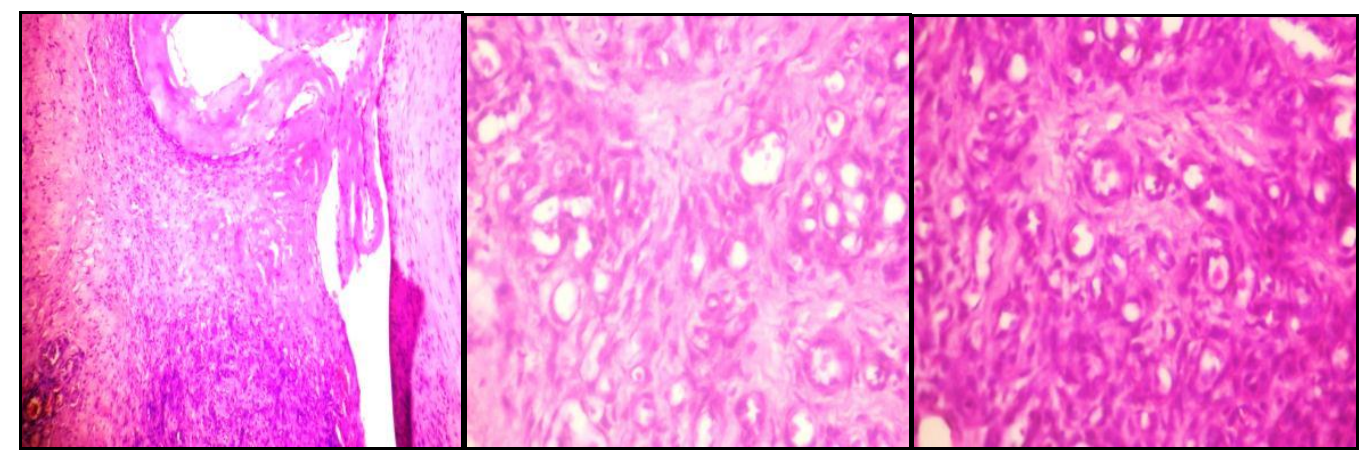

Fig 1 : H \& E Stained 4X

20X

20X

Collection of blood vessels which are small sized Collection of small blood vessels and also and contain RBC

collection of endothelial cells. 


\section{AUTHORS:}

1. D. Prem Charles

2. K. Murali

3. C.S. Subramanian

4. U. Manohar

5. P. Viswanathan

\section{PARTICULARS OF CONTRIBUTORS:}

1. $2^{\text {nd }}$ Year Post Graduate, Department of Pathology, Rajah Muthiah Medical College, Annamalai University.

2. $2^{\text {nd }}$ Year Post Graduate, Department of Surgery, Rajah Muthiah Medical College, Annamalai University.

3. Professor, Department of Surgery, Rajah Muthiah Medical College, Annamalai University.

4. Professor, Department of Pathology, Rajah Muthiah Medical College, Annamalai University.
5. Professor, Department of Pathology, Rajah Muthiah Medical College, Annamalai University.

\section{NAME ADRRESS EMAIL ID OF THE}

\section{CORRESPONDING AUTHOR:}

Dr. P. Viswanathan,

Professor, Department of Pathology,

Faculty of Medicine,

Rajah Muthiah Medical College,

Annamalai University, Chidambaram,

Tamilnadu, India, PIN - 608002.

Email - drpviswanathan2013@gmail.com

Date of Submission: 29/07/2013.

Date of Peer Review: 30/07/2013.

Date of Acceptance: 29/08/2013.

Date of Publishing: 30/08/2013 